\title{
Enterprise Performance Management System Construction Based on Strategy Organization
}

\author{
Yuxing Dong ${ }^{1, *}$ \\ ${ }^{1}$ Faculty of Business Administration, Shandong Women's University, Ji'nan, Shandong, China \\ *Corresponding author. Email: sdwudyx@126.com
}

\begin{abstract}
With the rapid development of economic globalization, competition in all industries continues to grow; people-oriented management concept has been emphasized in enterprise management. However, there is no perfect enterprise performance management system. In this paper, by using the theory of strategic performance management, we build a set of ideal performance management system for the strategy organization.
\end{abstract}

\section{Keywords: strategy, performance management, Key Performance Indicator, Balanced Score Card}

\section{INTRODUCTION}

Through performance management, managers can timely identify obstacles in the projects and correct the deviations to achieve team goals. For employees, managers' performance feedback helps them clearly understand their strengths and adjust their career development path. Employees discipline their behavior by setting their performance goals. Regular assessment and evaluation enables employees to keep their job responsibilities in mind and actively strive to achieve the strategic objectives of the organization. At the organization level, understanding the company development status through scientific, comprehensive, and effective performance management evaluation and formulating a complete enterprise management system and development strategy would help the company occupy a place in the fierce market competition.

Strategic performance management has become an indispensable part of enterprise human resource management. The quality of the strategic performance management system has a direct impact on human resource management. It determines whether the enterprise's strategic goals can be achieved or not. Strategic performance management is an enterprise that utilizes a variety of ways to decompose the organization's objectives to each level based on strategic goals and plans. Strategic performance management ensures employees' positive behavior and attitude. It maintains the consistency of the performance objectives at a lower level and the organization level so that the enterprise can achieve its strategic goals. In addition, strategic performance management, in the long-term, promotes the sustainable development of the enterprise, carries out reformation and innovation, and enhances the competitiveness of the enterprise.

\section{PROBLEMS IN ENTERPRISE PERFORMANCE MANAGEMENT}

\section{A. Performance appraisal targets are not set scientifically}

At present, enterprises carry out performance appraisal on departments and employees. Profit maximization is the ultimate goal pursued by enterprises. Therefore, during the department or the employee's performance appraisal, the enterprise mainly focuses on financial indicators. However, individual development plays a vital role in enterprise performance improvement but rarely considered. At the same time, due to the different functions of departments, enterprises undertake different businesses. Still, the final performance assessment is often taken by one or several departments that cannot play a completely independent role in the overall assessment process of enterprises.

\section{B. Lack of performance communication in the performance appraisal process}

Enterprises sometimes neglect enterprise strategy, but actually, it is an essential factor that affects their sustainable development. Also, they may lack accurate and precise performance management plans, and fail to build a scientific and practical performance management system to promote the sustainable development of enterprises. Besides, some performance appraisal systems are inconsistent with enterprises' strategic goals. Because employee appraisal only 
evaluates individual goals, not the overall enterprise goals. Thus, this performance appraisal system unable to assist the company in achieving its strategic objectives.

\section{Performance appraisal results are not fully applied}

The non-feedback of performance appraisal discourages employees and reduces the overall enterprise performance. The human resource management department may not have a clear understanding of the performance management system and would not consider it a dynamic system. They could miss the real function of performance management. It is not only used as an employee evaluation tool for salary purposes but also served as an employee improvement tool to motivate the staff's working enthusiasm and creativity, and then to help the team learn and grow. Besides, the performance appraisal can be used as a standard for training, transfer, promotion, and layoff, creating a flexible incentive system accepted by all employees to encourage employees.

\section{THE NECESSITY AND FEASIBILITY OF ESTABLISHING AN ENTERPRISE PERFORMANCE MANAGEMENT SYSTEM}

Managers often use performance appraisal to assess employee performances and determine the salary, reward, and punishment of employees. The purpose of performance management is to achieve the enterprise's strategic goals. But the goals cannot be reached through performance appraisal alone. It requires the enterprise to build a strategy-oriented performance management system and a strategic performance management system.

The enterprise should design the performance goals according to the enterprise strategy. From the perspective of system theory, the design of a performance management system should firstly formulate a performance plan and determine performance objectives, because the performance goal system determines the final goal of the management system. And the performance goal is consistent with the enterprise strategy and determined by this strategy. The performance goal system is the core system of a performance management system.

In the implementation of corporate strategy, it is necessary to use scientific performance management tools and methods to ensure the completion of the plans. The establishment of a sound performance management system becomes an essential guarantee for the successful implementation of enterprise strategy. Through the implementation of the performance management system, individual developments, department goals, and enterprise strategy will be connected together to improve the performance of individual, department as well as the enterprise. This will ultimately lead to the success of the enterprise and create a win-win situation between employees and the enterprise.

\section{THE DESIGN OF STRATEGIC-ORIENTED ENTERPRISE PERFORMANCE MANAGEMENT SYSTEM}

\section{A. Principles of performance management system design}

The implementation of enterprise performance management needs to be supported by a scientific and effective performance management system. So that the performance management can be implemented in scientific, systematic, and comprehensive ways. The design of the performance management system should have the following principles:

1) Principle of openness: The examiners and examinees should have a clear understanding of the design basis and assessment criteria of performance appraisal indicators and can reach a consensus. In the implementation process, the examinee's suspicion of the assessment standards should be avoided. Also, the assessment should be fair.

2) Principle of communication: Examiners and examinees should conduct sincere and continuous communication throughout the assessment process. The examiners should timely and accurately feedback the assessment results, affirm the achievements of the examiners, and guide the improvement of the existing shortcomings. When different opinion occurs, instant communication should be conducted to eliminate misunderstandings and encourage examinees.

3) Principle of objectivity: The examiners should not have a personal bias or use subjective thoughts to analyze, evaluate, communicate, and give feedback to the examinees. In the whole process of assessment, the examinees must only consider facts.

4) Principle of regularity: Performance management is a daily work of managers at all levels. Assessment, evaluation, and guidance employees regularly would keep the whole department moving forward around the development strategy of the enterprise.

5) Principle of the developmental strategy: Through the performance appraisal, the examinees are encouraged, and their behaviors are also disciplined and corrected. This would establish a competitive mechanism to promote employees' development. The primary purpose of performance appraisal is to improve individual and organization performance to enhance the 
overall performance of the enterprises. We should not treat assessment as a tool to exclude or suppress others.

\section{B. The construction of the performance management system}

Enterprises could construct a systematic, comprehensive, scientific, and effective strategic performance management system by using performance management tools such as the balanced scorecard method, the key performance indicator method, and the work analysis method to effectively measure the work behavior, performance of various departments and employees. Enterprises can create an open and fair evaluation of the assessment and give full play to the incentive and guidance mechanism of performance management, tapping the potential of employees so that employees can continue to learn. The performance of enterprises will improve.

1) The construction of the enterprise performance evaluation index system based on the balanced scorecard: The enterprise should make clear strategic development direction and determine the strategic goal, based on the position of each department. According to the job requirements of each department, the KPI evaluation method and the BSC method are applied for designing, establishing the performance evaluation index system of the department, and working out the corresponding target responsibility statement. Enterprises can analyze indicators of the department based on the work analysis method and the case study method. They can summarize and establish the index database, select the key factor indicators of success based on the job requirements. They can use the weight factor method to set the weight of indicators.

2) The construction of the employee performance appraisal index system based on job analysis: Enterprises can decompose the target, analyze the job description of each position, and formulate the corresponding job description based on the department of job analysis. Meanwhile, enterprises can determine the basic information, job purposes, job responsibilities and tasks, working relationship with other departments, post authority, responsibilities, qualifications, and key performance indicators. All employees should work following their job responsibilities and tasks. All competent departments should know their job responsibilities clearly and use their management authority accurately. They should implement the management system and further decompose the key elements of the departments' success into the employee performance appraisal indicators to set it up.

\section{Design of performance management process system}

Based on the actual condition of the enterprise, we can summarize the performance management process system. This system can be divided into the following six parts: determination of performance appraisal indicators, performance appraisal and performance evaluation, performance feedback, performance appeal, performance improvement, and application of performance results.

\section{Performance management system evaluation}

The implementation of the department performance management system is a process of designing the corresponding assessment index system according to the requirements of enterprise performance management. We should use the relevant assessment tools to judge the enterprise value based on assessment standards. Then we can decompose the enterprise strategic goals to the departments' performance goals. A good department performance management system can reflect the strategic goals of the enterprise. The system can keep a high consistency with the strategic goals and coordinate the business, operation, finance, customer service, regional center, human resources, and other departments of the enterprise. Keeping the balanced relationship among indicators, determining the expectations of stakeholders through key performance indicators, enterprises could finally achieve the realization of corporate strategic goals. The balanced scorecard is used to measure the balance between financial and non-financial, internal and external, managerial and operational performance, long-term and short-term goals, and outcomes and processes.

The implementation of the employee performance management system is a process of evaluating employee performance levels based on employee work behavior and work performance. Through the assessment, managers can find the problems in the work of employees and then solve them so that employees can clearly understand their position responsibilities and shoulder the mission. A good employee performance management system is established on the basis that employees' personal goals are consistent with department goals and enterprise goals, to ensure the realization of organizational performance.

\section{THE IMPLEMENTATION OF STRATEGIC ENTERPRISE PERFORMANCE MANAGEMENT SYSTEM}

The implementation of the performance management system is for the smooth completion of performance appraisal indicators. The implementation is the process of performance communication, performance feedback and coaching. It can also 
determines whether the management ability of managers can be improved, whether the quality and ability of employees can be improved, whether employees can get long-term development, and the most important is whether the performance goal can be achieved. In the implementation of the enterprise performance management system, it is mainly expounded from the two aspects of manager performance, feedback and guidance, and performance process management.

\section{A. Performance feedback and coaching}

Through collecting feedback and coaching, managers can communicate with employees. They can also convey the strategic direction of the enterprise to employees to improve enterprise performance. Managers should evaluate employees working behavior objectively and reasonably. Usually, they should let employees know the influence of their behavior on departments and enterprises, even on other employees. Managers should also cultivate employees working ability, innovation ability by communicating with employees, and performance feedback so that employees can improve their working methods and attitude. The overall performance of enterprises will also improve.

\section{B. Performance process management}

During the implementation of performance management, managers should emphasize the role and purpose of coaching so that employees can pay attention to this. Managers should also understand the situation of employees by communicating with them and collect employee's information. Managers and employees should discuss the desired goals and how to solve problems at work together, and then both of them should set a time for the next meeting.

\section{THE SAFEGUARD FOR THE OPERATION OF THE STRATEGIC ENTERPRISE PERFORMANCE MANAGEMENT SYSTEM}

\section{A. Identifying critical players for implementation}

First, identify the key players in the implementation of the performance management system, as well as their roles and tasks. All employees are critical participants in the implementation of the enterprise performance management system. Employees' behaviors and results will have an impact on enterprise performance. They can provide strong support for the realization of strategic enterprise performance.

\section{B. Actively organizing the support and cooperation of internal staff}

Strategic performance management, which is related to the strategic development direction of the enterprise and the sustainable development of the enterprise, needs the overall support and cooperation of the enterprise. Senior managers should highly value the performance management system and let all employees actively participate in the activities of the enterprise. Middle managers should master the corresponding theory of strategic performance management and use the relevant management tools and methods to support the implementation and performance of the management system. The final foothold of performance lies in the grass-roots employees of the enterprise, who complete the department and enterprise performance by completing their individual performance.

\section{Strengthening performance management training}

Through training, managers and employees can understand the relationship between various departments in the performance management system and other aspects of the enterprise. They can recognize the significance and value of the implementation of the performance management system and accept it. Through training, managers will improve the quality of all aspects of the staff and regulate their behavior to enhance their performance.

\section{Motivating participants to implement the performance management system}

To effectively motivate the participants, enterprises should make the team pay attention to the implementation value of the performance management system, make them actively participate in the implementation structure, and promote the realization of performance objectives. Managers should link compensation to employees' performance in the implementation process to motivate them to perform their duties better.

\section{E. Correctly handling the relationship between strategic performance and other systems}

Enterprise performance management system, whose mainline is strategic performance, can correctly handle the relationship between "strategic performance" and other management systems, such as business plan and financial budget management, process management, ability quality model, the pay packages. These relationships are all the support of the implementation of strategic performance and could guarantee the external and internal conditions for the operations.

\section{$F$. Good performance communication is the guarantee of performance implementation}

Performance communication plays an essential role in the implementation of the performance management system and runs through the whole implementation process. Through effective communication, managers can timely find the existing problems of employees, and 
correct the errors to improve efficiency. At the same time, employees can report their procedures and issues to leaders to seek help and support from managers.

\section{CONCLUSION}

Establishing a scientific and perfect strategic performance management system is an essential way to improve the core competitiveness of enterprises. Optimizing and reconstructing the enterprise performance management system, as well as making reasonable measures to ensure the realization of enterprise strategy, play very important roles in the strategic development of enterprises.

\section{References}

[1] Cao Xufang and Wu Jigui. Research of performance evaluation of logistics enterprise operation department based on DEA-AHP [J]. Logistics Engineering and Management, 2013(02).

[2] Ge Qingqing. Performance evaluation decision analysis of logistics enterprises in China based on BSC [D]. Hei Longjiang University, 2013.

[3] Zhao yarong. Problems existing in the application of key performance indicator assessment method and countermeasures [J]. Economic and Trade Practice, 2017(07).

[4] Liu Dong. Study on the performance management of tobacco commercial enterprises [J]. Shandong Social Sciences, 2016(S1):171-172.

[5] Yuan Fang, Chen Siliang. Discussion on optimal path of enterprise performance management $[\mathrm{J}]$. Accounting Study, 2017(11): 184-186.

[6] Liu Ming. Discussion on innovative measures of enterprise performance management $[\mathrm{J}]$. Business Theory of China, 2018(16):113-114.

[7] Yang Hua. Analysis on the application of performance management theory in enterprises $[\mathrm{J}]$. The Human Resources, 2019(04): 73-74 